\title{
Multimodality Imaging for Radiosurgical Management of Arteriovenous Malformations
}

\author{
Ferrat Dincoglan, Omer Sager ${ }^{8}$, Selcuk Demiral, Murat Beyzadeoglu \\ ${ }^{1}$ Department of Radiation Oncology; University of Health Sciences, \\ Gulhane Medical Faculty, Ankara, Turkey \\ *Corresponding author's email: omersager [AT] gmail.com
}

\begin{abstract}
---
Background: Cerebral arteriovenous malformations (AVMs) are rarely seen congenital vascular anomalies. AVMs may lead to intracranial hemorrages due to disorganized tangle of vessels. Lifetime risk of bleeding from AVMs may be significant given the diagnosis at typically earlier ages of the lifespan, and complications associated with hemorrhage may lead to substantial morbidity or mortality. Management of AVMs aims at eliminating or reducing the risk of subsequent bleeding. In this context, microvascular surgical resection, endovascular embolization and radiosurgical treatment may be used for management of AVMs.

Objective: In this study, we assessed the incorporation of Magnetic Resonance Imaging (MRI) in treatment planning for AVM radiosurgery.

Methods: We identified 25 patients receiving radiosurgery for AVMs at our institution. Radiosurgery target volumes generated by using CT-only based imaging and CT-MR fusion based imaging for each patient were evaluated.

Results: Twenty five patients undergoing SRS for AVMs were evaluated for target volume determination in this study. Mean target volume was 4.9 cc (range: 1.3-15.9 cc) on CT-only imaging, and 5.7 cc (range: 1.4-16.7 cc) on CT-MR fusion based imaging. Target definition based on CT-MR fusion based imaging was identical to the consensus decision of all treating physicians in majority of patients.

Conclusions: Treatment planning for AVM radiosurgery may be improved by incorporating CT-MR fusion based imaging, which clearly should be supplemented with additional data from angiography. There is need for additional studies to establish a consensus on optimal target definition by multimodality imaging for SRS of AVMs.
\end{abstract}

Keywwords--- stereotactic radiosurgery (SRS), arteriovenous malformation (AVM), target volume, magnetic resonance imaging (MRI)

\section{INTRODUCTION}

Cerebral arteriovenous malformations (AVMs) are rarely seen congenital vascular anomalies which are found in $0.01-0.05 \%$ of the population mostly at the 3rd and 4th decades [1,2]. AVMs may lead to intracranial hemorrages due to disorganized tangle of vessels. Lifetime risk of bleeding from AVMs may be significant given the diagnosis at typically earlier ages of the lifespan, and complications associated with hemorrhage may lead to substantial morbidity or mortality [2-5].

Management of AVMs aims at eliminating or reducing the risk of subsequent bleeding. In this context, microvascular surgical resection, endovascular embolization and radiosurgical treatment may be used for management of AVMs. Stereotactic Radiosurgery (SRS) has been utilized for management of several benign and malign indications with considerable success [6-24]. In the context of AVMs, surgery offers effective management of AVMs in selected patients, however, radiosurgery may be considered when there may be an excessive risk of surgical complications for deep-seated lesions located at eloquent brain regions. Several studies have reported 3-year obliteration rates in the order of $60 \%$ to $90 \%$, with safe and effective management of AVMs using SRS, even for larger lesions by use of staged procedures $[2,3,8,25-30]$.

Nevertheless, SRS is not devoid of complications [31,32]. The risk of radiosurgical complications correlate with irradiated volume. From this standpoint, accurate target volume determination has been an indespensable part of successful radiosurgery applications. Considering that adverse radiation effects may be an important aspect of SRS, precision is warranted for treatment to improve the therapeutic ratio.

Initial detection of AVMs is typically based on cross-sectional imaging. Presence of a nidus and arteriovenous shunting are critical components of establishing the diagnosis. In addition to Computed Tomography (CT) simulation, treatment planning for radiosurgery requires incorporating different imaging modalities such as Magnetic Resonance Imaging (MRI) and cerebral angiography. While cerebral angiopraphy may offer a viable imaging modality for diagnosis, treatment planning, and follow up of the patients, MR images may be fused with planning CT images for 
improving target determination for SRS of AVMs. In this study, we assessed the incorporation of MRI in treatment planning for AVM radiosurgery.

\section{METHODS}

We identified 25 patients receiving radiosurgery for AVMs at our institution. SRS was performed after informed consent of the included patients and decision making for treatment with radiosurgery was decided by a multidisciplinary team of experts on neurosurgery, neuroradiology, and radiation oncology. Details of the radiosurgery procedure was described previously [8]. Briefly, a stereotactic head frame was affixed to the patients' skull under local anesthesia, supplemented with sedation if necessary. Contrast-enhanced planning CT images were acquired at CT simulator (GE Lightspeed RT, GE Healthcare, Chalfont St. Giles, UK) available at our department using a slice thickness of $1.25 \mathrm{~mm}$. After completion of image acquisition at the CT simulator, image data sets were sent to the delineation workstation (SimMD, GE, UK) for contouring of target volume and critical structures in close neighbourhood of the target. For the purpose of our study, determination of target volumes was based on either CT simulation images only or by fusion of T1 gadolinium-enhanced volumetric Magnetic Resonance (MR) images acquired within 1 week before radiosurgery. The 2 target volumes generated by using CT-only based imaging and CT-MR fusion based imaging for each patient were evaluated. Ground truth target volume for each patient was decided by consensus, colleague peer review, and collaboration of the treating physicians to be used for actual patient treatment and comparative assessment of generated target volumes. The radiosurgery planning system used in this study was ERGO ++ (CMS, Elekta, UK) and treatment machine was Synergy (Elekta, UK) Linear Accelerator (LINAC) with $3 \mathrm{~mm}$ thickness head-on micro multileaf collimator. In radiosurgery planning, a single 360-degree arc, double 360-degree arcs, or five 180-degree arcs were selected to achieve the institutional planning objectives. Windows and levels of the planning CT simulation images were adjusted to improve target and critical structure visualization. Coronal and sagittal images were used in addition to axial images to achieve improved target and critical structure contouring accuracy. Target coverage and normal tissue sparing was further optimized by use of Arc Modulation Optimization Algorithm. Median dose was 18 Gy (range: 12-20 Gy) prescribed to the $85 \%-95 \%$ isodose line encompassing the target volume. Setup verification was secured by use of $\mathrm{kV}$ CBCT (kilovoltage Cone Beam CT) and XVI (X-ray Volumetric Imaging, Elekta, UK) system. All patients received intravenous dexamethasone with $\mathrm{H} 2$-antihistamines immediately after radiosurgical treatment.

\section{RESULTS AND DISCUSSION}

Twenty five patients undergoing SRS for AVMs were evaluated for target volume determination in this study. Mean target volume was $4.9 \mathrm{cc}$ (range: $1.3-15.9 \mathrm{cc}$ ) on CT-only imaging, $5.7 \mathrm{cc}$ (range: $1.4-16.7 \mathrm{cc}$ ) on CT-MR fusion based imaging, and $5.9 \mathrm{cc}$ (range: 1.4-16.9 cc) on consensus decision of all treating physicians with colleague peer review. Target definition based on CT-MR fusion based imaging was identical to the consensus decision of all treating physicians in majority of patients. Figure 1 shows the AVM lesion (black arrow) of a patient on axial and coronal planning CT and MR images. 


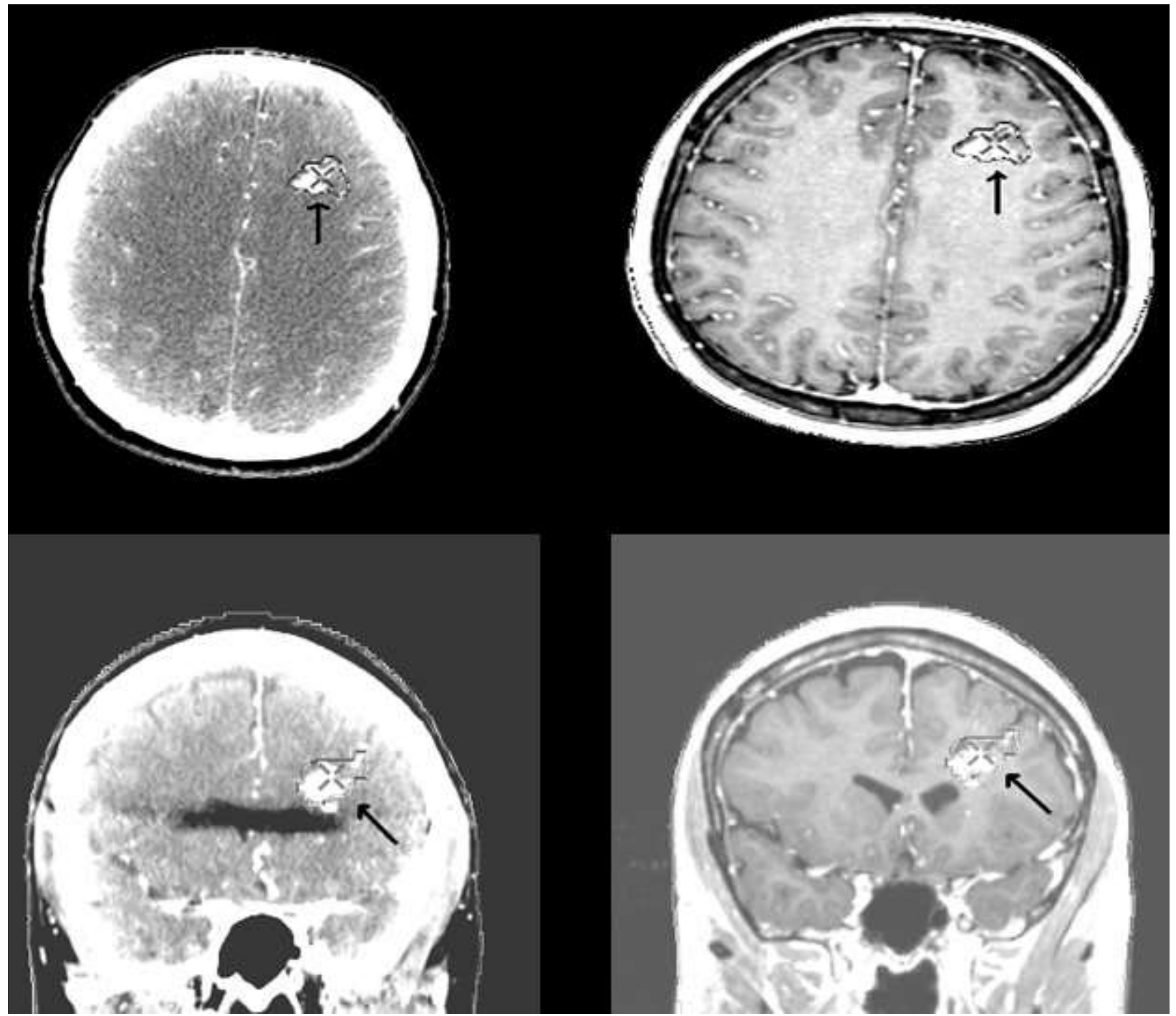

Figure 1- AVM lesion (black arrow) of a patient on axial and coronal planning CT and MR images.

Radiosurgery has been judiciously used for reducing the risk of hemorrhages in adult and pediatric patients with AVMs [33-35]. Several studies using LINAC radiosurgery or gamma knife radiosurgery consistently revealed significant decrease in future bleeding risk after SRS along with early return to normal daily living activities [33-35].. Repeat radiosurgery has also been used for safe and effective management of selected patients [36].

Our study adds to the literature by demonstrating improved target determination with incorporation of multimodality imaging in treatment planning for AVM radiosurgery. It has been shown in several studies that targeting errors may lead to suboptimal outcomes for patients receiving SRS for AVMs [37-39]. While inadequate definition of the nidus may substantially reduce obliteration rates, inclusion of excessive normal brain tissue within the target volume may result in adverse radiation effects. In this context, improving the accuracy of target determination becomes more critical considering the delivery of high dose radiation in a single session with SRS. Since MR images may provide additional information which may be utilized for improved target definition, complementing planning CT images with fusion of MRI may offer precise targeting. Nevertheless, accuracy of target determination warrants further imaging data such as angiography for achieving the best results.

\section{CONCLUSIONS}

In conclusion, treatment planning for AVM radiosurgery may be improved by incorporating CT-MR fusion based imaging, which clearly should be supplemented with additional data from angiography. There is need for additional studies to establish a consensus on optimal target definition by multimodality imaging for SRS of AVMs.

\section{LIMITATIONS}

Despite its advantages such as offering a noninvasive treatment modality, there may be a risk of consequent bleeding during the period after SRS of AVM [40-44]. In this context, continued follow up of patients may be considered 
even after obliteration of AVM after SRS. Also, optimal target definition by multimodality imaging should be further investigated in the context of treatment planning for AVM radiosurgery.

\section{ACKNOWLEDGEMENTS}

The authors have no acknowledgements and no conflicts of interest.

\section{REFERENCES}

[1] Halim AX, Johnston SC, Singh V, McCulloch CE, Bennett JP, Achrol AS, Sidney S, Young WL. Longitudinal risk of intracranial hemorrhage in patients with arteriovenous malformation of the brain within a defined population. Stroke, vol. 35, no. 7, pp. 1697-1702, 2004.

[2] Fleetwood IG, Steinberg GK. Arteriovenous malformations. Lancet, vol. 359, no. 9309, pp. 863-873, 2002.

[3] Flemming KD, Lanzino G. Management of Unruptured Intracranial Aneurysms and Cerebrovascular Malformations. Continuum (Minneap Minn),vol. 23, no. (1), pp. 181-210, 2017.

[4] Ondra SL, Troupp H, George ED, Schwab K. The natural history of symptomatic arteriovenous malformations of the brain: a 24-year follow-up assessment. J Neurosurg, vol. 73, no. 3, pp. 387-391, 1990.

[5] Brown RD Jr, Wiebers DO, Forbes GS. Unruptured intracranial aneurysms and arteriovenous malformations: frequency of intracranial hemorrhage and relationship of lesions. J Neurosurg, vol. 73, no. 6, pp. 859-863, 1990.

[6] Sirin S, Oysul K, Surenkok S, Sager O, Dincoglan F, Dirican B, Beyzadeoglu M. Linear accelerator-based stereotactic radiosurgery in recurrent glioblastoma: a single center experience. Vojnosanit Pregl, vol. 68, no. 11, pp. 961966, 2011.

[7] Dincoglan F, Beyzadeoglu M, Sager O, Oysul K, Sirin S, Surenkok S, Gamsiz H, Uysal B, Demiral S, Dirican B. Image-guided positioning in intracranial non-invasive stereotactic radiosurgery for the treatment of brain metastasis. Tumori, vol. 98, no. 5, pp. 630-635, 2012.

[8] Dincoglan F, Sager O, Gamsiz H, Demiral S, Uysal B, Surenkok S, Sirin S, Oysul K, Beyzadeoglu M. Management of Arteriovenous Malformations by Stereotactic Radiosurgery: A Single Center Experience. Int J Hematol Oncol, vol. 22, no. 2, pp. 107-112, 2012.

[9] Surenkok S, Sager O, Dincoglan F, Gamsiz H, Demiral S, Uysal B, Sirin S, Oysul K, Beyzadeoglu M. Stereotactic Radiosurgery in Pituitary Adenomas: A Single Center Experience. Int J Hematol Oncol, vol. 22, no. 4, pp. 255-260, 2012.

[10] Dincoglan F, Sager O, Gamsız H, Uysal B, Demiral S, Dirican B, Oysul K, Surenkok S, Sirin S, Beyzadeoglu M. Stereotactic radiosurgery for intracranial tumors: a single center experience. Gulhane Med J, vol. 54, no. 3, pp. 190-198, 2012.

[11] Sager O, Beyzadeoglu M, Dincoglan F, Demiral S, Uysal B, Gamsiz H, Oysul K, Dirican B, Sirin S. Management of vestibular schwannomas with linear accelerator-based stereotactic radiosurgery: a single center experience. Tumori, vol. 99, no. 5, pp. 617-622, 2013.

[12] Demiral S, Beyzadeoglu M, Uysal B, Oysul K, Kahya YE, Sager O, Dincoglan F, Gamsiz H, Dirican B, Surenkok S. Evaluation of stereotactic body radiotherapy (SBRT) boost in the management of endometrial cancer. Neoplasma, vol. 60, no. 3, pp. 322-327, 2013.

[13] Dincoglan F, Beyzadeoglu M, Sager O, Uysal B, Demiral S, Gamsiz H, Dirican B. Evaluation of linear acceleratorbased stereotactic radiosurgery in the management of meningiomas: a single center experience. J BUON, vol. 18, no. 3 , pp. 717-722, 2013.

[14] Sager O, Beyzadeoglu M, Dincoglan F, Uysal B, Gamsiz H, Demiral S, Oysul K, Dirican B, Sirin S. Evaluation of linear accelerator (LINAC)-based stereotactic radiosurgery (SRS) for cerebral cavernous malformations: a 15-year single-center experience. Ann Saudi Med, vol. 34, no. 1, pp. 54-58, 2014.

[15] Sager O, Beyzadeoglu M, Dincoglan F, Gamsiz H, Demiral S, Uysal B, Oysul K, Dirican B, Sirin S. Evaluation of linear accelerator-based stereotactic radiosurgery in the management of glomus jugulare tumors. Tumori, vol. 100, no. 2, pp. 184-188, 2014.

[16] Gamsiz H, Beyzadeoglu M, Sager O, Dincoglan F, Demiral S, Uysal B, Surenkok S, Oysul K, Dirican B. Management of pulmonary oligometastases by stereotactic body radiotherapy. Tumori, vol. 100, no. 2, pp. 179-183, 2014.

[17] Dincoglan F, Sager O, Gamsiz H, Uysal B, Demiral S, Oysul K, Sirin S, Caglan A, Beyzadeoglu M. Management of patients with $\geq 4$ brain metastases using stereotactic radiosurgery boost after whole brain irradiation. Tumori, vol. 100, no. 3, pp. 302-306, 2014.

[18] Demiral S, Beyzadeoglu M, Sager O, Dincoglan F, Gamsiz H, Uysal B, Oysul K, Gundem E, Dirican B, Sirin S. Evaluation of Linear Accelerator (Linac)-Based Stereotactic Radiosurgery (Srs) for the Treatment of Craniopharyngiomas. Int J Hematol Oncol, vol. 24, no. 2, pp. 123-129, 2014.

[19] Gamsiz H, Beyzadeoglu M, Sager O, Demiral S, Dincoglan F, Uysal B, Onal E, Dirican $\quad B$. Evaluation of stereotactic body radiation therapy in the management of adrenal metastases from non-small cell lung cancer. Tumori, vol. 101, no. 1, pp. 98-103, 2015. 
[20] Sager O, Dincoglan F, Beyzadeoglu M. Stereotactic radiosurgery of glomus jugulare tumors: current concepts, recent advances and future perspectives. CNS Oncol, vol. 4, no. 2, pp. 105-114, 2015

[21] Dincoglan F, Beyzadeoglu M, Sager O, Demiral S, Gamsiz H, Uysal B, Ebruli C, Akin M, Oysul K, Sirin S, Dirican B. Management of patients with recurrent glioblastoma using hypofractionated stereotactic radiotherapy. Tumori, vol. 101, no. 2, pp. 179-184, 2015.

[22] Demiral S, Dincoglan F, Sager O, Gamsiz H, Uysal B, Gundem E, Elcim Y, Dirican B, Beyzadeoglu M. Hypofractionated stereotactic radiotherapy (HFSRT) for who grade I anterior clinoid meningiomas (ACM). Jpn J Radiol, vol. 34, no. 11, pp. 730-737, 2016.

[23] Dincoglan F, Sager O, Demiral S, Uysal B, Gamsiz H, Dirican B, Beyzadeoglu M. Radiosurgery for recurrent glioblastoma: a review article. Neurol Disord Therap, vol.1, no. 4, pp. 1-5, 2017.

[24] Demiral S, Dincoglan F, Sager O, Uysal B, Gamsiz H, Ozcan F, Dirican B, Beyzadeoglu M. Contemporary Management of Meningiomas with Radiosurgery. Int J Radiol Imaging Technol, vol. 4, pp. 041, 2018.

[25] Colombo F, Pozza F, Chierego G, Casentini L, De Luca G, Francescon P. Linear accelerator radiosurgery of cerebral arteriovenous malformations: an update. Neurosurgery, vol. 34, no. 1, pp. 14-20, 1994.

[26] Ding D, Starke RM, Kano H, Mathieu D, Huang P, Kondziolka D, Feliciano C, Rodriguez-Mercado R, Almodovar L, Grills IS, Silva D, Abbassy M, Missios S, Barnett GH, Lunsford LD, Sheehan JP. Radiosurgery for Cerebral Arteriovenous Malformations in A Randomized Trial of Unruptured Brain Arteriovenous Malformations (ARUBA)Eligible Patients: A Multicenter Study. Stroke, vol. 47, no. 2, pp. 342-349, 2016.

[27] Cenzato M, Boccardi E, Beghi E, Vajkoczy P, Szikora I, Motti E, Regli L, Raabe A, Eliava S, Gruber A, Meling TR, Niemela M, Pasqualin A, Golanov A, Karlsson B, Kemeny A, Liscak R, Lippitz B, Radatz M, La Camera A, Chapot R, Islak C, Spelle L, Debernardi A, Agostoni E, Revay M, Morgan MK. European consensus conference on unruptured brain AVMs treatment (Supported by EANS, ESMINT, EGKS, and SINCH). Acta Neurochir (Wien), vol. 159, no. 6, pp. 1059-1064, 2017.

[28] Sirin S, Kondziolka D, Niranjan A, Flickinger JC, Maitz AH, Lunsford LD. Prospective staged volume radiosurgery for large arteriovenous malformations: indications and outcomes in otherwise untreatable patients. Neurosurgery, vol. 62, Suppl. 2, pp. 744-754, 2008.

[29] Seymour ZA, Sneed PK, Gupta N, Lawton MT, Molinaro AM, Young W, Dowd CF, Halbach VV, Higashida RT, McDermott MW. Volume-staged radiosurgery for large arteriovenous malformations: an evolving paradigm. J Neurosurg, vol. 124, no. 1, pp. 163-174, 2016.

[30] Pollock BE, Link MJ, Stafford SL, Lanzino G, Garces YI, Foote RL. Volume-Staged Stereotactic Radiosurgery for Intracranial Arteriovenous Malformations: Outcomes Based on an 18-Year Experience. Neurosurgery, vol. 80, no. 4, pp. 543-550, 2017.

[31] Meneghelli P, Pasqualin A, Zampieri P, Longhi M, Foroni R, Sini A, Tommasi N, Nicolato A. Surgical Management of Adverse Radiation Effects After Gamma Knife Radiosurgery for Cerebral Arteriovenous Malformations: A Population-Based Cohort Study. World Neurosurg, vol. 114, pp. e840-e850, 2018.

[32] Monaco EA 3rd, Niranjan A, Kano H, Flickinger JC, Kondziolka D, Lunsford LD. Management of adverse radiation effects after radiosurgery for arteriovenous malformations. Prog Neurol Surg, vol. 27, pp. 108-118, 2013.

[33] Pollock BE, Gorman DA, Coffey RJ. Patient outcomes after arteriovenous malformation radiosurgical management: results based on a 5- to 14-year follow-up study. Neurosurgery, vol. 52, no. 6, pp. 1291-1296, discussion 1296-1297, 2003.

[34] Wang YC, Huang YC, Chen HC, Wei KC, Chang CN, Lee ST, Wu CT, Tseng CK, Wang CC, Chen YL, Hsu PW. Linear accelerator stereotactic radiosurgery in the management of intracranial arteriovenous malformations: long-term outcome. Cerebrovasc Dis, vol. 37, no. 5, pp. 342-349, 2014.

[35] Park CK, Choi SK, Lee SH, Choi MK, Lim YJ. Clinical outcomes and radiosurgical considerations for pediatric arteriovenous malformation: influence of clinical features on obliteration rate. Childs Nerv Syst, vol. 33, no. 12, pp. 2137-2145, 2017.

[36] Stahl JM, Chi YY, Friedman WA. Repeat radiosurgery for intracranial arteriovenous malformations. Neurosurgery, vol. 70, no. 1, pp. 150-154, discussion 154, 2012.
[37]
Pollock
BE, Kondziolka
D, Lunsford
LD, Bissonette
D, Flickinger
JC.

Repeat stereotactic radiosurgery of arteriovenous malformations: factors associated with incomplete obliteration.

Neurosurgery, vol. 38, no. 2, pp. 318-324, 1996.

[38] Pollock BE, Flickinger JC, Lunsford LD, Maitz A, Kondziolka D. Factors associated with successful arteriovenous malformation radiosurgery. Neurosurgery, vol. 42, no. 6, pp. 1239-1244, 1998.

[39] Ellis TL, Friedman WA, Bova FJ, Kubilis PS, Buatti JM. Analysis of treatment failure after radiosurgery for arteriovenous malformations. J Neurosurg, vol. 89, no. 1, pp. 104-110, 1998.

[40] Yen CP, Sheehan JP, Schwyzer L, Schlesinger D. Hemorrhage risk of cerebral arteriovenous malformations before and during the latency period after GAMMA knife radiosurgery. Stroke, vol. 42, no. 6, pp. 1691-1696, 2011.

[41] Zabel-du Bois A, Milker-Zabel S, Huber P, Schlegel W, Debus J. Risk of hemorrhage and obliteration rates of LINAC-based radiosurgery for cerebral 
arteriovenous malformations treated after prior partial embolization. Int J Radiat Oncol Biol Phys, vol. 68, no. 4, pp. 9991003, 2007.

[42] Shin M, Kawahara N, Maruyama K, Tago M, Ueki K, Kirino T. Risk of hemorrhage from an arteriovenous malformation confirmed to have been obliterated on angiography after stereotactic radiosurgery. J Neurosurg, vol. 102, no. 5, pp. 842-846, 2005.

[43] Maruyama K, Kawahara N, Shin M, Tago M, Kishimoto J, Kurita H, Kawamoto S, Morita A, Kirino T. The risk of hemorrhage after radiosurgery for cerebral arteriovenous malformations. N Engl J Med, vol. 352, no. 2, pp. 146-153, 2005.

[44] Yen CP, Schlesinger D, Sheehan JP. Natural history of cerebral arteriovenous malformations and the risk of hemorrhage after radiosurgery. Prog Neurol Surg, vol. 27, pp. 5-21, 2013. 